\title{
Changing Identity in Small or Minority Nations: Three Recent Catalan Films
}

DOI:

10.1080/24741604.2019.1589266

\section{Document Version}

Accepted author manuscript

Link to publication record in Manchester Research Explorer

\section{Citation for published version (APA):}

Jones, D., \& Perriam, C. (2019). Changing Identity in Small or Minority Nations: Three Recent Catalan Films. Bulletin of Spanish Visual Studies, 2019, 1-27. https://doi.org/10.1080/24741604.2019.1589266

\section{Published in:}

Bulletin of Spanish Visual Studies

\section{Citing this paper}

Please note that where the full-text provided on Manchester Research Explorer is the Author Accepted Manuscript or Proof version this may differ from the final Published version. If citing, it is advised that you check and use the publisher's definitive version.

\section{General rights}

Copyright and moral rights for the publications made accessible in the Research Explorer are retained by the authors and/or other copyright owners and it is a condition of accessing publications that users recognise and abide by the legal requirements associated with these rights.

\section{Takedown policy}

If you believe that this document breaches copyright please refer to the University of Manchester's Takedown Procedures [http://man.ac.uk/04Y6Bo] or contact uml.scholarlycommunications@manchester.ac.uk providing relevant details, so we can investigate your claim.

\section{OPEN ACCESS}


'Changing Identity in Small or Minority Nations: Three Recent Catalan Films'

\title{
[COVER PAGE]
}

Author details:

Dilys Jones, University of Manchester

Chris Perriam, University of Manchester

(Corresponding author: christopher.perriam@manchester.ac.uk)

ORCID identifier: 0000-0002-5664-8389

\begin{abstract}
:
The article places three recent Catalan films in a framework of classificatory discussion of identity, change and small or 'minority' nationhood. It builds on previous work on Welsh and Basque film which proposes a system of classification designed to enhance the conceptualisation of links between film and identity in small or minority national cultures. That system uses three modal concepts: the Preserved, connected with patriarchy, rural landscape, collective rural identity, and stereotypical representations; Reversal, connected with complexities and ambiguities of meaning as produced by representations of landscape or expressions of collective identity; and the postnational, connected to qualities of discordance, placelessness, and scepticism about the relevance or direction of collective history. Los últimos días (David and Álex Pastor, 2013), Segon origen (Carles Porta, 2015) and Estiu 1993 (Carla Simón, 2017) are analysed using the categorisation in order to explore how crises and changes in individuals or communities link to wider processes of transition and regression. It draws on previous schematisations by Williams and Castells and places particular emphasis on nuancing the conceptualisation of the postnational in the small or minority cultural context.
\end{abstract}

Keywords:

Catalan film; classificatory method; landscape; identity; the postnational

Figures:

x 6, separate files at Dropbox link:

Table:

$\mathrm{x} 1$, separate file attached

Word count:

11,000 [revised] 


\section{Changing Identity in Small or Minority Nations: Three Recent Catalan Films}

This article seeks to place three recent Catalan films, each with a claim to transnational cultural prominence, in a framework of classificatory discussion of identity, change and small or 'minority' nation status. ${ }^{1}$ In chronological order of release, the films are Los últimos dias (David and Álex Pastor, 2013), Segon origen (Carles Porta, 2015) and, the most prominent of these films, Estiu 1993 (Carla Simón, 2017) which has won major prizes within Catalunya and beyond. Each of these films has a crisis as its narrative origin and dramatises a classic shock of change to the identity of a character, a family or a community. This kind of change more or less directly, and more or less obliquely, connects within the films and in their reception to processes of transition and regression at the level of social structure, territory (physical, mental, and commercial), people or nation. The article builds on previous work on Welsh and Basque film by Dilys Jones which proposes a system of classification designed to 'take the conceptualisation of links between film and identity' further than can classifications

\footnotetext{
${ }^{1}$ As discussed, for example in Mette Hjort and Duncan Petrie, 'Introduction', in The Cinema of Small Nations, ed. Mette Hjort and Duncan Petrie (Edinburgh: Edinburgh University Press, 2007), 1-20; Michael Keating, 'The Minority Nations of Spain and European Integration: A New Framework for Autonomy?', Journal of Spanish Cultural Studies, 1:1 (2000), 29-42.
} 
such as (minority) national, or heritage. ${ }^{2}$ The system uses three modal concepts as lenses under which to study films from, about, or in relation to minority nations. These are: the Preserved, connected with patriarchy, rural landscape, collective rural identity, and stereotypical representations; Reversal, connected with a deconstructive critique of the dualistic assumptions underlying the filmic mode of the Preserved, and involving an exploration of complexities and ambiguities of meaning as produced by landscape or expressions of collective identity; and the postnational, whose lower case 'p' signals its permeability to elements in the previous two categories but which attends to how ideas of national identity have become pluralised and which is connected to qualities of discordance, placelessness, and scepticism about the relevance or direction of collective history. ${ }^{3}$ The system is proposed as a fruitful way of establishing the salient features of, and of nurturing new meanings within, films such as those under discussion in this article-films that grow out of, and nourish, small and minority national consciousness. It draws on previous schematisations: by Raymond Williams (for the concepts of Dominant, Residual, and Emergent cultures) and Manuel Castells (for the concepts of Legitimizing, Resistance and

\footnotetext{
2 Dilys Jones, 'Changing Narratives of Identity in Welsh and Basque Film', in The Media in Europe's Small Nations, ed. Huw David Jones (Newcastle upon Tyne: Cambridge Scholars Publishing, 2014), 87-104 (p. 87)the article has a full explication of the uses of the model, as does Dilys Jones (2013) 'Changing narratives of minority peoples' identities in Welsh and Basque Film', Doctoral dissertation (University of Wales Trinity Saint David, 2013); available at http://ethos.bl.uk/OrderDetails.do?uin=uk.bl.ethos. 741082 (accessed 2 June 2018). See also, for different applications of the model, Dilys Jones, 'Territories, Existence and Identities: Indigenous Peoples Argentine Films', in Human Rights, Social Movements and Activism in Contemporary Latin American Cinema, eds. Mariana Cunha and Antônio Márcio da Silva (London: Palgrave Macmillan, 2018), 95-112. ${ }^{3}$ See the table at the conclusion of this article.
} 
Project Identities). ${ }^{4}$ In the current article we propose first to further explore the ideas of Castells. We then move on to consider a range of scholars who have usefully revisited the itself residual notion of the postnational. In particular, our discussion of recent Catalan films —films from a specific, and increasingly complicated, minority national context—will remain alert to how, as Stacy Schmitt Rusnak has observed, "[t]he "post" in postnational does not designate a specific temporal moment since the post-national and national have existed and continue to exist side by side' and how 'instead of hinging on binary formations of "otherness", the postnational allows for a fluidity that takes into consideration [certain extranational] issues [...] as they increasingly impact culture and politics'. ${ }^{5}$ Rusnak's issues for the purposes of her own analysis of Alfonso Cuarón's Children of Men (2006) and Agamben's ideas on exception and crisis are: 'immigration, diasporic communities, exile, political asylum, terrorism, and technology';6 our own equally impactful issues will be: no less than the destruction of community and civilisation and their possible resurrection on Catalan soil, in Los últimos dias and Segon origen; and, in Estiu 1993, the deterritorializing and alienating effects of grief on a young individual displaced to an iconic Catalan heartland and an alternative family structure that both, nonetheless, offer the character and the viewer a therapeutic new sense of belonging.

\footnotetext{
${ }^{4}$ Raymond Williams, Marxism and Literature (Oxford: Oxford University Press, 2009 [1st ed .1977]); Manuel Castells, The Power of Identity, vol. 2 of The Information Age: Economy, Society and Culture (Chichester: Wiley Blackwell, 2010 [1st ed. 1997]), xvii-xxxvi.

5 Stacy Schmitt Rusnak, 'When "Nation" Stops Making Sense: Mexico and Giorgio Agamben's "State of Exception" in Children of Men', in The Postnational Fantasy: Essays on postcolonialism, cosmopolitics and science fiction, ed. Masood A. Raja, Jason W. Ellis, and Swaralipi Nandi (Jefferson, NC: McFarland \& Co, 2011), 174-187 (p. 177).

6 Rusnak, ‘When “Nation” Stops Making Sense’, 177.
} 
In the main body of the discussion the aim, then, is to test the suitability for close readings of these individual films of a system originally designed (like the prior schematisations it draws on) to consider much wider socio-cultural scenarios and flows. A second aim is that of nuancing the conceptualisation of the postnational in the small or minority cultural context.

\section{Identity Categories}

Manuel Castells's The Power of Identity (1997) famously, though not unproblematically, 'explores' (in his own words) 'the construction of identities as they relate to social movements and power struggles in the network society'; and 'the construction and assertion of identity' is there 'detected [...] as being a fundamental lever of social change'. ${ }^{7}$ The power of identity is central to his analysis of globalization and of the ways in which 'the more the world becomes global, the more people feel local': '[t]erritorial identity is a fundamental anchor of belonging'. 8 Put another way, by Kathryn Crameri and in direct relation to questions of Catalan nationalism, '[p]paradoxically, as globalisation progresses, so does fragmentation, especially in the form of a heightened attachment to a particular identity' .9

\footnotetext{
${ }^{7}$ Manuel Castells, 'Preface to the 2010 edition of The Power of Identity' in The Power of Identity, vol. 2 of The Information Age: Economy, Society and Culture (Chichester: Wiley Blackwell, 2010 [1st ed. 1997]), xvii-xxxvi. (p. xvii); on some of the problems with Castells's approach see John MacInnes, 'Castells' Catalan routes: nationalism and the sociology of identity', The British Journal of Sociology, 57:4 (2006), 677-698.

8 Castells, 'Preface', xxiii.

${ }^{9}$ Kathryn Crameri, Goodbye, Spain? The Question of Independence for Catalonia (Eastbourne: Sussex Academic Press, 2014), 140.
} 
This particular identity (relating to people, home, nation, language, culture) is caught up in the processes of the three identity categories proposed by Castells. The first of these is Legitimizing, 'built by an élite' from its own purview, 'introduced by the dominant institutions of society to extend and rationalise their domination vis-à-vis social actors' — for example the Spanish State in relation to Catalunya, Euskadi, and Galicia; ${ }^{10}$ most film narratives in Jones's category of Preserved respond to the legitimizing identity construction processes by reproducing or representing a basic power relationship between minority nation and a dominant oppressor and might include, as Catalan examples, El Pianista (Mario Gas, 1998), Numax Presenta (Joaquim Jordà, 1980), Companys: próces a Catalunya (José or Josep Maria Forn, 1979), Caracremada (Lluís Galter, 2010), Els fosses del silenci (Montse Armengou and Ricard Belis, 2003: TV3). To take one of our example films, in Los últimos dias, the Legitimizing, dominant presence of destructive global capitalism is powerfully asserted in early flashbacks scenes where protagonist Marc (Quim Gutiérrez) and his colleagues in a multinational company are facing the threat of redundancy in a downsizing operation. The mise-en-scène and lighting use classic but effective tactics to dramatize the moment, with employees hedged about by the open-plan office's glass and steel-edged dividers in a cold blue-grey light coming in laterally and emphasizing facial features. As the company's hit-man approaches Marc's desk, the low camera angle and low ceilings of the office space magnify his threatening demeanour and when Marc swivels round from his datacrowded screen to confront him it is with a face marked by shadows and apprehension. This vignette is a premonition, as will be seen, of the larger effects of the imposition of Legitimizing power.

\footnotetext{
${ }^{10}$ Manuel Castells and Martin Ince, Conversations with Manuel Castells (Oxford: Polity Press, 2003, 69; Castells, Power of Identity, 8; and Castells, 'Preface', xxiv.
} 
The second set of identities are Resistance identities (also present in the films just listed) in which 'nations as cultural communities have become trenches of mobilization and resistance against secular repression of their rights and identities' — against, that is, the structural domination of the would-be legitimisers. ${ }^{11}$ These are '(historically grounded) national' identities, 'strong [...] simple and solid in their workings'. ${ }^{12}$ While some strands in films representing this type of strong identity may operate in the mode of Reversal, or, as we shall now adapt it, the Reversed—overturning traditional judgements, morals, mores and suppositions, and deconstructing dualisms - others may simultaneously refer back to the narratives of identity in the mode of the Preserved, due to a dependency on opposition to assertions of legitimacy and power or to ambiguities in their commitment to breaking with tradition. So, for example, La teta y la lluna (Bigas Luna, 2005) will not work as satire without the grudging, ambiguous acknowledgment of the ubiquity of machismo, the fragility of regional assertions of national identities, or — much less grudgingly — the power of heterosexual desire. Similarly, of course, Emilio Martínez-Lázaro's Ocho apellidos vascos (2014) and Ocho apellidos catalanes (2015) play with comical indeterminacy on the overlapping of Reversed and Preserved. In Segon origen survivors Alba (Rachel Hurd-Wood) and Dídac (Ibrahim Mané), having reached what is left of Barcelona, pick through the ruins of the Biblioteca de Catalunya for material to help them in the utterly overturned, reversed, world they find themselves in. Old knowledge is turned to the new purpose of constructing an identity out of destruction and adversity. The camera tracks Alba's (unrealistically) unblemished face from one side of a shelf of books as she looks out useful texts on plants, food and child-rearing and -naming. In this brief archival sweep the texts of the Catalan past

\footnotetext{
11 Castells, 'Preface', xxiv; Castells, Power of Identity, 129.

12 Castells, 'Preface', xxiv; Castells, Power of Identity, 129.
} 
(although at least one book is in Castilian) line up, in the sunlit ruins, an alternative destiny. For the audience slow to read these things, in the following sequence Alba's voice-over explicates the point, referencing change and noting 'portarem una nova vida al mon'. What they are carrying through is a process of resistance to the ultimate destruction of identity.

Thirdly, Project Identities imply the transformation of the overall social structures and emerge 'when social actors, on the basis of whatever cultural materials are available to them, build a new identity that redefines their position in society and, in so doing, seek [such a] transformation' for example, 'feminism in our context and environmentalism'.13 Such identities are, in their collective manifestation, proactive movements which aim at transforming society as a whole, rather than merely establishing the conditions for their own survival in opposition to the dominant actors; ${ }^{14}$ as to individuals, they achieve holistic meaning for themselves through the creation by Project Identities of personal histories and social actions in an interplay of local and global processes. In Estiu 1993 the rural existence of Marga (Bruna Cusí) and Esteve (David Verdaguer) is clearly represented as Project (with strong touches of Preserved imagery of nature and community) through dialogue initiated by Marga about building a particular lifestyle for themselves and their toddler daughter. Wardrobe also simply accentuates their lives as Project: while Marga wears colourful, loosefitting tops, simple short skirts or striped shorts and Marc un-ironed, open-necked shortsleeved shirts, Esteve's parents when they visit are in a formal beige two-piece suit and pearl earring set in gold, for his mother, and jacket (over his arm or over a chair), long-sleeved shirt and tie for his father. The distance between urban, bourgeois living and life in the country is also enhanced by framing and shot distance as the parents arrive (up a dusty track) and depart

\footnotetext{
13 Castells, 'Preface', xxxvi.

14 Castells, Power of Identity, 8.
} 
(in a car that is delicately used to mark the several transitions and differences--geographical, emotional, temporal--in the film).

In descending order of prominence, Project, Resistance and Legitimizing identities inform the changing narratives of small or minority nation identities in film, as seen through the imaginary characters and plots in films set in a Catalan rural and urban landscapes that are either recognizable precisely because of the enhancing strangeness wrought by catastrophe or because of their apparently unchanging iconicity. Similarly, in differing degrees, our three films have elements that traffic with, and are focussed through, the Preserved, the Reversed, and — in this case most of all — the postnational. Castells's empirical research is interested in the real, lived world (despite sidelining class), and in how individuals and groups may enact resistance to political oppression and his theories are large-scale (and problematically diffuse with regard to assumptions about 'society', 'territory', 'nation' and, even, 'identity'. ${ }^{15}$ Nevertheless, the analysis of specific filmic representation that can be undertaken using the system of Preserved, Reversed, postnational can intersect productively with Castells's grander sociological scheme, and may, perhaps, suggest some further nuancing of the meta-language around changing identities in minority nations' cultures. This article begins by setting Castells's general understanding or theorisation of how power may operate and how it may be resisted alongside some specifics of small or minority national history, culture, community, and relations with the dominant; and it does so within the conceptual frame of the postnational (in Jones's sense). It thus seeks to couple a methodology of categorisation with an awareness of the fine-grained production of feeling and meaning within the films and in critical responses to them.

\footnotetext{
${ }^{15}$ See Mervyn F. Bendle, 'The crisis of “identity” in high modernity', British Journal of Sociology, 53:1 (2002), 1-18; and MacInnes, 'Castells' Catalan routes'.
} 


\section{Postnational, Minority, Catalan}

The idea of the 'postnational', emerging as an influential, and contested, term in the $1990 \mathrm{~s}$, is famously influenced in part by postmodern theory and its re-imagination of selfhood in terms of: fragmentation, decentredness and lack of impulse to seek coherence; ${ }^{16}$ of a social condition marked by an intellectual turn in which 'ephemerality and fragmentation take precedence over eternal truths and unified politics';17 and of a worldview fractured by 'incredulity toward metanarratives'.18 In terms of cultural production, Fredric Jameson's characterisation of Postmodernism, as glossed by Nick Hefferman, includes a 'quality of depthlessness, severing [cultural products] from the kinds of meaningful connections with history which realists and modernist forms [had] struggled to establish'. ${ }^{19}$ Jones's findings on Welsh and Basque film and changing narratives of minority national identity established that open, or unresolved characters and plots, a lack of stable manifestations of gender, family structure or generational difference, and a relative disintegration of strictly national identity

16 See Fredric Jameson, Postmodernism, or, The Cultural Logic of Late Capitalism (Durham NC: Duke University Press, 1991) and Walter T. Anderson, The Future of the Self: Inventing the Postmodern Person (New York: Jeremy P. Tarcher/Putnam, 1997).

17 David Harvey, The Condition of Postmodernity (Oxford : Blackwell Publishers Ltd., 1990), 339.

18 Jean-François Lyotard, The Postmodern Condition: A Report on Knowledge, trans. Geoff Bennington and Brian Massumi (Minneapolis: University of Minnesota Press, 1984), xxiv.

${ }^{19}$ Nick Hefferman, ‘Frederic Jameson', in Contemporary Critical Theorist: From Lacan to Said, ed. Jon Simons (Edinburgh: Edinburgh University Press, 2004), 260. 
categories are markers there of the postnational. ${ }^{20}$ Those Welsh and Basque films, as postnational phenomena and representations of the postnational, were also found to construct a sense of broken community, with bonds to the past (to tradition) and to the landscape in the present, or as a basis for the future, problematised, weakened or broken, with narrative, dramatic and psychological features such as dislocation and a 'sense of identity mislaid' ${ }^{21}$ Such features are significant structural strands in the Catalan films that are the present concern, even though these are cultural products strongly supported, positioned and mediated by some of the collective identity-affirming processes typical of small nations and nations without a state. ${ }^{22}$

These are small nation films as identified by Mette Hjorte and Duncan Petrie. ${ }^{23}$ They are produced within a particular relationship to globalising flows and discourses of nation building as well as within a limited market with its own structures of support (for example, through the organisation Catalan Films and TV) and subvention (through the Departament de Cultura of the Generalitat de Catalunya and the Institut Català de les Empreses Culturals). A resurgence of debate, conflict, and popular and political actions around issues of nation, state, sovereignty, self-determination, independence, cultural and linguistic difference in the mid-2000s to the time of writing has added particular urgency to questions concerning the role of the small nation — questions of collective belonging, hybridity and purity, boundaries

\footnotetext{
20 Jones, 'Changing Narratives of Identity', 97-99.

21 Jones, 'Changing Narratives of Identity', 100-102 (p. 102).

22 As studied by Montserrat Guibernau i Berdún, Nations without States (Cambridge: Polity Press, 1999) and Keating, 'The Minority Nations'.

23 Hjort and Petrie, 'Introduction', 13-18.
} 
and identities. ${ }^{24}$ Such questions highlight the 'precarious balance between a diverse fragmented nation and a multiply fractured one'. 25 More widely, these and cognate films come into, and are made out of, the circulation of transcendent global identities, mediatised and enabled by transnational flows of goods and perceptions which prompt anxieties and uncertainties about the local and the given. ${ }^{26}$ The Catalan film and television industries, and independent Catalan filmmakers whatever their relation to the institutionalised industry (for example, as manifested by the organisation Catalan Films \& TV), are inevitably caught up in the web of producing distinctive, somehow local, cultural products and identity images in an environment of digitised globalisation — caught up, that is, in the 'predicament' attendant on 'the smallness of small national cinemas' .27

Using as a departure point Raymond Williams's essay 'The Culture of Nations', Martine Danane, in a discussion of French cinema, underlines how 'the globalisation phenomenon has $[\ldots]$ not superseded national cultures but transformed them into increasingly complex manifestations complicating the role of the nation-state', balancing between 'homogenization and heterogeneity, or the universal and the particular'. ${ }^{28}$ Joanne Hershfield, writing about transnational Mexican cinema, notes that:

\footnotetext{
24 Steve Blandford, 'Foreword', in The Media in Europe's Small Nations, ed. Huw David Jones (Newcastle upon Tyne: Cambridge Scholars Publishing, 2014), ix-xi.

25 Andrés Zamora, Featuring Post-National Spain: Film Essays (Liverpool: Liverpool University Press, 2016), 179.
}

26 Ulf Hedetoft and Mette Hjort, The Postnational Self: Belonging and Identity (Minneapolis: University of Minnesota Press, 2002), x-xvi.

27 Hjort and Petrie, 'Introduction', 17.

${ }^{28}$ Martine Danane, 'National and Post-national French cinema', in Theorising National Cinema, ed. Valentina Vitali and Paul Willeman (London: British Film Institute, 2006), 172-85 (pp. 182-83). 
Post-national cinema speaks about and responds to social formations that articulate varied and sometimes conflicting senses of the ideological and physical limits of the nation as well as the diverse relations of subjects to the nation. It is most profoundly articulated through thematic and narrative zones of conflict, especially those that address gender, race, national origin, regional affiliations and class. Post-national cinema is necessarily a hybrid cinema that draws on national as well as transnational cinematic styles, genres and narrative and aesthetic practices 29

Danane, for example, interprets French cultural policy into the early 2000s as positioning French cinema as having 'reached the limits of its "Franco-French" logic'; 30 and she sees it moving towards a synergetic combination of the auteurist (for prestige and brand) and the postnational (for global reach and marketability). ${ }^{31}$ The Catalan cases under discussion in this article can be seen to have a similar 'new postnational-national dialectic' in their combinations of specific local tropes, narratives and myths with those packaged up into the genres of the larger-scale industry. 32 This dialectic also entails engagement with the conceptual 'zones of conflict' discussed by Hershfield. Estiu 1993's Catalan rurality and

\footnotetext{
${ }^{29}$ Joanne Hershfield, 'Nation and post-nationalism: the contemporary modernist films of Carlos Reygadas', Transnational Cinemas, 5:1 (2014), 28-40, (p. 30). doi: 10.1080/20403526.2014.891330; Hershfield draws for theoretical and terminological framing on Arjun Appadurai, Modernity at Large: Cultural Dimensions of Globalization (Minneapolis: University of Minnesota Press, 2006) and Thomas Elsaesser, European Cinema: Face to Face with Hollywood (Amsterdam: Amsterdam University Press, 2005).

30 Danane, 'National and Post-national', 176.

${ }^{31}$ Danane, 'National and Post-national', 181.

32 Danane, 'National and Post-national', 181.
} 
community becomes the stage for a family drama of disruption and for the fragmenting effects of grief and the healing processes of its narrativisation; our two post-apocalyptic films use territory and posterity (Catalan/Mediterranean or urban Catalan) to make their postnational appeal as Brave New World narratives. Their zones of conflict include: family and national histories; regeneration; personal politics; urban and rural imaginaries; ecology; capitalism; belonging.

\section{Los últimos días and Segon origen: Preserved, Post-apocalyptic, postnational, and}

\section{Project}

This section will begin by focusing on the limits, yet persistence, of the national—-the Catalan —in Los últimos dias and thinking about the film in terms of the postnational, writ small. It will also explore how its small postnational and large-scale post-apocalyptic features coalesce to make it into a minor Project Identity cultural product. In this majority Castilian-language film, Marc and Júlia are living a millennial middle-class life in their apartment in the Eixample of Barcelona, he working long hours as an IT specialist for the company already mentioned, she painting and designing and working for a small outlet in a city centre shopping mall. Gradually on the news it transpires that a mysterious epidemic, The Panic, is spreading across the globe in parallel with, and perhaps associated with, an extensive volcanic ash cloud disrupting air travel; it causes acute agoraphobia. From home, Marc sees their neighbour succumb; at work, one colleague's erratic performance because of the syndrome makes him a victim of Enrique (José Coronado) who has been assigned to the office to weed out under-performers. Forcibly ejected from the building, he has a seizure and 
dies. Soon everyone becomes trapped—in Barcelona and world-wide—and Enrique's imminent persecution of Marc is curtailed. Telecommunications and the flow of goods and food, and eventually water, are disrupted. In the second narrative frame three months on, from which there are flashbacks to pre-Panic times, Marc sets off on a subterranean quest to find Júlia, accompanied by Enrique, in an uneasy pact hingeing on a stolen GPS device. Enrique wishes to get to his stroke-stricken father in the Hospital del Mar. Marc succeeds, tracking Júlia down at her gynaecologist's consulting rooms on the city's Via Laietana; Enrique does not, dying in the already abandoned Laietana Multicines opposite, into which they have tunnelled.

In the 2014 Catalan Academy of Cinema Gaudí awards the film won in the categories of Best Film not in the Catalan Language, Special/Visual Effects, Cinematography (Daniel Aranyó), Sound (Licio Marcos de Oliveira, Oriol Tarragó, David Calleja), Make-Up and Hairstyles (Patricia Reyes), Art Direction (Balter Gallart), and Production Management (Josep Amorós). It is strongly grounded in its revisualisation of the incrementally devastated Catalan capital seen in one contemporary newspaper report on the making of the film as 'monumental, icònica i espectacular' but also very much not the city of tourist cliché, but a horribly familiar one. ${ }^{33}$

The logistics of shooting made local audiences keenly aware of the film—with huge construction works for Barcelona metro's Line 9 facilitating certain scenes of tunnelling and devastation and complicated arrangements for closing off the Via Laietana being covered widely in the local press. The special effects are admired and decried in more or less equal

\footnotetext{
33 Julián García, 'Apocalipsi a Barcelona. Els germans Àlex i David Pastor relaten la seva experiència en el rodatge del film sobre la fi del món Los últimos días', <https://www.elperiodico.cat/ca/oci-i-cultura/20130330/ apocalipsi-a-barcelona-2351578> (accessed 4 January 2018).
} 
measure by the non-academic commentators. ${ }^{34}$ They are indeed spectacular, drawing not only on the brother directors' own development of uncanny imagery in the similarly virus-based Carriers (2009) but also on a combination of increasingly sophisticated digital technology in post-apocalyptic and dystopian feature film and video-game graphical know-how. As is apparent from the plot synopsis, and as many point out, the film draws widely on global cognate genres and intertexts in cinematic terms: on post-catastrophe and post-apocalypse films, on near-future fantasy or dystopia films, on tales of the end of days; and specifically, on The Happening (M. Night Shyamalan, 2008), I Am Legend (Francis Lawrence 2007) and The Ultimate Warrior (Robert Clouse 1975) as well as on a slim but sustained stream of similar genre film from Spain, from Alejandro Amenábar, Jorge Torregrossa and others. ${ }^{35}$ In old-fashioned terms, then, in several ways the film combines the local and the global. The local lies in the bilingual but mostly Catalan street signs and other notices, the metro station names, the occasional irruption of Catalan on the Castilian audio track (including a key plot twist concerning Enrique's father's fate), and in the images of the remains of the environment built by famed Catalan architects and planners. In a sequence at just over the halfway point in the film (and much used in trailers and publicity imagery) the camera tilts up from closely tracking leaves across a tarmac surface to reveal in the middle distance the Arc de Trionf, with storm clouds in the background and an abandoned car, an overturned van and refuse bin

\footnotetext{
34 For example, practitioner Paco Galindo offers both points of view: 'Los últimos días: impactante Barcelona apocalítica', <http://www.norender.com/los-ultimos-dias-impactante-barcelona-apocaliptica/> (accessed 4 January 2018).

35 These borrowings are picked up on variously by: Gregorio Belinchón, 'El fin del mundo entrará por España', $<$ https://elpais.com/cultura/2013/03/26/actualidad/1364326864_004487.html > (accessed 4 January 2018); Jordi Costa, 'Apocalipsis, (aquí y) ahora', <https://elpais.com/cultura/2013/03/26/actualidad/ 1364321798_235034.html> (accessed 4 January 2018); and Mikel Zorrilla, 'Los últimos días, el incidente', $<$ https://www.espinof.com/criticas/los-ultimos-dias-el-incidente $>$ (accessed 4 January 2018).
} 
on the road in the foreground. An upward swoop of the crane gives a shot of a reindeer sedately crossing - one of many animals that have escaped from the nearby zoo, now serving as shorthand for mayhem. The global—perhaps also signalled by the escaped animals motif - lies in the non-Catalan intertextualities mentioned above, in the obvious and generic allusions to the times of crisis in which it is made, in its adoption of a now familiar softcritical anti-capitalism mingled with a diffusely ecological sensitivity, to which we will return, and in its wanting to be 'el relato de un tiempo, el nuestro, condenado'. ${ }^{36}$

The film is replete with allegorical signals of a preoccupation with the destructive effects of neoliberal economics and of global business practices on the organisation of human life in the modern nation state. The effects of the (global) Panic are focalised through Marc and first seen directly in the office space and the building's foyer and forecourt: the links between it and a generalised sense of crisis as experienced by the millennial generation are clear. The office becomes a space which combines the Sartrian hell of No Exit with concepts such as those used in the Barcelona-set novel El alquiler del mundo (Pablo Sánchez, 2010) and the more specifically Catalan drama El mètode Grönholm by Jordi Galceran, made into the Castilian-dialogue, transnationally-cast film El método (Marcelo Piñeyro, 2005). As such, then, the film fits the model of postnationalist expressions of loss of identity and importance in a context of supranational and global power structures and flows. In the first narrative timeframe, Marc's job is stressfully futile (as he repeatedly fails to crack a digital puzzle needed for the company to gain the upper hand); he and his colleagues are in the firing line of Enrique (whom they nickname the Terminator); and in his relationship with Júlia his unwillingness to commit to having children centres on his perception of the world as unfit to

\footnotetext{
${ }^{36}$ Luis Martínez 'El apocalipsis, más o menos', <http://www.elmundo.es/elmundo/2013/03/27/cultura/ 1364379276.html $>$ (accessed 4 January 2018).
} 
bring in a newborn into. Unjustly, ending a key argument on this issue, he accuses Júlia of burying her head in the sand and, like everyone else, taking refuge in the false securities of the routines of work and consumerism. In the second narrative timeframe, as he and Enrique talk of fear and failure in a ruined church (having just survived an attack by a rampaging but frightened bear loose from the Barcelona zoo), their conversation constructs their current plight as a diffuse fable, based around a remembered news story, of the self-destructiveness of modern, Western human development in contrast to the destiny of a group of Australian aborigines who had been widely reported (while the media were still functioning) to be immune to The Panic. Those people, they surmise, might have known something that we others never did. Later, after a suicide attempt by Enrique- - whose father's death in the ruins of the Hospital del Mar is confirmed to him-again the two turn to a tale of deterministic self-destruction whereby all was over long ago and nobody wished to face the fact.

\{FIGURE 1 of 6 near HERE.

\section{Caption: Marc (Quim Gutiérrez) witnessing Enrique's (José Coronado) suicide attempt in Los últimos días, with the Hospital del Mar in ruins in the background. (C) Morena Films S.L.\}}

These more widely catastrophist perceptions move the film away from its potential critique of financialised life towards an equally generic story of generational irresponsibility and ecological catastrophe. This is balanced by a utopian discourse of futurity (based around Júlia's pregnancy and the eventual birth of a child) and the emergence of an imagery of radically repurposed sustainability. Júlia is envisioned by Marc in several flashbacks at moments of extreme stress floating through green young woodland in one of several 
moments of 'estética publicitaria'. ${ }^{37}$ Enrique the managerial destroyer turns seed-collector during the quest, scavenging sunflower seeds, popcorn cast-offs, pips and stones, the fruits of all of which extravagantly enrich the film's last five minutes. There, Baby Enric, born to Marc and Júlia, gurgles and crawls amid the growing plants in a repurposed apartment in the Via Laietana building where the parents had ended up, and then — miraculously immune — out on the overgrown street in the film's time-compacted epilogue. As a teenager he joins a band of healthy young mega-ramblers - also allegorically immune-who echo that tribe of aborigines whose superior being-in-the-world had also saved them (as recalled by Marc and Enrique). The youngsters stride off through the jungle-city into, one supposes, a better (and maybe bilingual) world. Film magazine Cinemanía, for one, not unfairly sees this final scene as very self-indulgent and lying somewhere between a New Age anthem and an advertisement for Perona backpacks and satchels. ${ }^{38}$ However, the scene gestures earnestly enough towards ecological (and anti-consumerist) arguments concerning the future of humanity, poignantly dramatised in this happy band of young Catalans striding inland and onwards. It encapsulates in filmic cliché a transformational Project Identity built up to throughout with instances of resistance to neoliberal, globalising, homogenising forces and with affirmations of the importance of affective solidarity and of care.

\{FIGURE 2 of 6 near HERE.

Caption: Dani (uncredited) heading towards a new future in Los últimos días. (C) Morena Films S.L.\}

\footnotetext{
37 Costa, 'Apocalipsis'.

${ }^{38}$ Manuel Piñón 'Los últimos días’, <http://cinemania.elmundo.es/peliculas/los-ultimos-dias/critica/> (accessed 4 January 2018).
} 
Our second post-apocalyptic film, Segon origen attempts a similar Project. It has a strong Mediterranean/Catalan pedigree, directed by producer and cultural polymath Carles Porta after a script idea by the iconic figure of Josep Joan Bigas i Luna (born Barcelona 1946, died La Riera de Gaià in rural Tarragona 2013 — to recall his home territory) and based on the Catalan sci-fi novel Mecanoscrit del segon origen of 1974 by Manuel de Pedrolo- $\mathrm{a}$ much revered, secondary-school syllabus text in Catalunya, still in print and still discussed.39 As the film's official website has it:

The whole of humanity has vanished. The only two survivors, the 20-year-old Alba and the 10-year-old Dídac, are living in a devastated world. In order to survive on this planet in ruins, they must start from scratch. Together they will have to rebuild not only their own lives but also those of the whole of humanity. Because when everything seems lost, love is the only survival handbook. ${ }^{40}$

This world, initially, is the rural environs of Lleida, where Alba has lived with her English father, an ecologist and climate-change expert; subsequent to the firestorm that ravages the world (but not all the crops), as the quest for survival takes hold, the scene shifts to a devastated Barcelona (once more), then to the Tarragona coastline and to Menorca. Dídac has grown into a man. The devastated world is a devastated Catalan nation, emphatically. It is out

\footnotetext{
39 See, for example, Jose Asensio 'Critica: Segon origen', <https:/elcriticoinquilino.wordpress.com/2015/11/05/ critica-segon-origen/> (accessed 4 June 2018).

${ }^{40}$ At $<$ http://www.segundoorigen.com/en/film/> (accessed 1 February 2018).
} 
of a lovingly filmed Catalan coastal and rural territory of natural richness, and from the fruit of Alba's womb and a bilingual Catalan-English coupling (Dídac and Alba) that humanity (a new Nation) will be born. Along the way, at their coastal makeshift home, a pirate-stranger —l'Home, The Man (Sergi López) — first befriends then betrays the couple, kidnapping their boy child, Kai, and sailing off to his Menorcan fortress hideout. They have to rescue Kai; the two men fight, and are killed. Alba, somehow, returns to the mainland. Kai (Dayron Vera) grows to be a toddler and, as the last part of Alba's voice-over narration (addressed to Dídac) affirms, will soon hear his mother's tales of his father's deeds.

The film, then, looks postnational in a number of the ways explored by Jones: it enacts an explosive rupture with family history — with the past - and with the Catalan nation's foundational land- and city-scapes; it envisages the disappearance of all community; there is a scaling down to individual characters in the context of a world that is both recognisably Catalan yet generically post-apocalytpic, a 'discordant landscape' par excellence. ${ }^{41}$ In its representation of motherhood it also adds, in an uneven way, a further telling case to those studied as 'reconfiguring the nation' and making for a 'Post-national Spain’ by Andrés Zamora.42 As Alba rides on her scooter, early on, on a long country road through blossoming fruit trees and is passed by a tractor the scene cuts to a close up of bees dead on the ground; just as in Julio Medem's Tierra (1996), where the character Mari's (Silke) transit of pest-threatened fields on a scooter signals a blighted community, so here the characters traverse a landscape inscribed with future destruction (the tractor, indeed, is itself a premonition and will feature in Dídac's and Alba's post-apocalytic quest).

\footnotetext{
41 Jones, 'Changing Narratives of Identity', 97-102 (p. 101).

42 Zamora, Featuring Post-National Spain, 137-73.
} 
\{FIGURE 3 of 6 near HERE: Alba (Rachel Hurd-Wood) riding through the doomed landscape in Segon origen. (C) Produccions Audiovisuals Antàrtida S.L.\}

Although the character of Alba as the new Mother of Humanity in an archaic and formulaic sense therefore bears some of the signs of the cinematic culture of the Preserved, she is for a number or reasons adrift from the possibility of connection with stable and symbiotic identity.

One of these reasons is linguistic, and it entails serious questions of identity and belonging. Although Alba is a language teacher of sorts (she helps the ten-year-old Dídac with his English) she is no language-learner herself - a far from trivial short-coming in terms of the arguments of Catalan linguistic nationalism — and the halting, tonally inauthentic Catalan (unlike the authentic but somewhat staid Castilian of the alternate audio track) of Hurd-Wood's dialogue seems credible at first but incredible once she has lived with the fluently native Catalan-speaking Dídac for long enough for him to grow up and father her child. On the one hand the film prompts the question: What sort of a nation could this be whose mother never grows up linguistically? On the other hand, though, the awkwardness of Alba's spoken Catalan itself highlights not just the language but a key set of issues entailed in the famous phrase of the third article of the 1979 Estatut d'Autonomia de Catalunya (the sixth in the 2016 version) — 'La llengua pròpia de Catalunya és el català'—and in the 1983 Llei de Normalització Lingüística and 1998 Llei de Política Lingüística. Though Catalan is co-official with Castilian, symbolically its weight is emphasised by the 'own language' 
designation, which accrues 'socio-political strength' ${ }^{43}$ Incomers may react in different degrees in their language-learning decisions in this complicated diglossic context to "the weight this language [Catalan] carries as a symbol of political identification' ${ }^{44}$ Alba clearly is identifying, and her liaison with Dídac — perhaps a second-generation African Catalan— connects her to a new multicultural as well as unequally bilingual Catalunya. With the catastrophe, and Alba's progress into the future, the linguistic scales are then tipped; Castilian is wiped away; the new nation will be, albeit imperfectly, Catalan-dominant with English in the background (in Alba's memory, as remembered sounds; and in her father's notebooks, as text).

\{FIGURE 4 of 6 near HERE:

\section{Caption: Alba and Dídac (Ibrahim Mané) arrive triumphant at their new campsite home in Segon origen. (C) Produccions Audiovisuals Antàrtida S.L.\}}

For all this Catalan futurity, there is a pervasive nostalgic element in the film - for youth, a new start, contact with the land; and for the mood of previous similar cinematic fantasies, such as The Blue Lagoon (Randal Klesier, 1980) and parts of The Beach (Danny Boyle, 2000). In reaching back like this it has more of the characteristics of the Preserved. In

\footnotetext{
43 Peter A. Kraus, 'Language policy and Catalan independence', in Catalonia in Spain and Europe: Is There a Way to Independence?, ed. Klaus-Jürgen Nagel and Stephan Rixen (Baden-Baden: Nomos Verlagsgesellschaft, 2015), 129-40, p. 133.

${ }^{44}$ Kraus, 'Language policy', 137.
} 
particular, once Alba and Dídac have settled on what had been the Las Palmeras campsite on the Platja Llarga near Salou on the coast of Tarragona province, there is a sense of an ideal Catalan Hippy Nation temporarily but precariously coming out of the ruins of the past; a landscape at once foundational and discordant. As Yago García observes, these parts of the film have 'una vibración muy del Principat y muy de los 70, evocando mediante su bucolismo mediterráneo ecos de María del Mar Bonet o de Pep Laguarda \& Tapinería' (these artists_-Mallorcan, in fact—being associated with folk pop and rock in the Catalan music scene). 45 As Carlos Marañón observes, the original novel's themes of youthful sexual awakening, 'una vuelta a la esencia, sol, tierra, agua' ('a return to the essence of things, the sun, the land, water') probably explain Bigas Luna's interest in it as material for a film project. ${ }^{46}$ These themes - and food (as is highlighted in the 2016 documentary Bigas $x$ Bigas directed by Santiago Garrido Rua) — are famously characteristic of Bigas Lunas's own filmmaking (and life); so too is a key visual and plot element in the last third of the film, the nurturing mother's breast as an object of erotic, formative and nostalgic interest. 47 These elements are clearly placed to signal change and rebirth through reconnection with the natural and maternal. And yet the project of making this new-old nation is subject to substantial disruption, as we have seen. If faith is to be put into humankind's newly relearned ability to

\footnotetext{
45 Yago García, ‘Segundo origen: El viaje postapocalíptico y “post mortem’”de Bigas Luna’, <http:// www.sensacine.com/peliculas/pelicula-190103/sensacine/> (accessed 4 January 2018).

46 Carlos Marañón, 'Segundo origen', <http://54.228.224.226/peliculas/segundo-origen/critica/> (accessed 4 January 2018).

47 See Dominic Keown, 'The Catalan Body Politic as Aired in La teta i la lluna', in Burning Darkness: A Half Century of Spanish Cinema, ed. Joan Ramon Resina (New York: SUNY Press, 2008), 255-276 and Abigail
} Loxham, 'Digesting the Image: Carnal Appetites and Ethical Consumption in the Work of Bigas Luna', in Food, Media and Contemporary Culture: The Edible Image, ed. Peri Bradley (London: Palgrave Macmillan, 2016), 203-19. 
nurture and cultivate, the ecological message is incoherent. The implication-a literalization of the more indirect allegory of Pedrolo's novel—is that the destruction of the Earth might have been prevented had humanity been a better caretaker. This is pointed to by: several short scripted homilies on the importance of caring for the land; Alba's tender reconstruction of her dead father's own ecological convictions and horticultural practices; her and Dídac's tending of their kitchen garden; through many references to fertility; and through a recurrent visual motif of bread-making (thanks to miraculously long-preserved grain stocks and unscathed though untended fields). However, the apocalypse is not, of course, brought about by human recklessness but by a massive solar storm (or, in the version we hear from Dídac's garagemechanic father, an alien invasion). Although the bucolic Mediterranean tone and some scenes of the inland Lleida landscape powerfully evoke continuity, stability and purity, nature is locally treacherous. The sun's rays initially kill, storm water destroys the kitchen garden crops, the sea is the realm of the perfidious L'Home and enables the kidnapping of little Kai. The otherwise idyllic isle of Menorca is L'Home's place of violent hoarding and acquisition. What sort of a future could this be that is built on such shifting ground? In brute terms of plot, of course, the torture and death of Dídac and Alba's killing in self-defence against L'Home mean that all that is preserved is the unpromising new and lonely start. This entails a return, to the environs of Lleida and to where the story began, by mother and rescued childa child who, though he grows up to look like Dídac, is not going to be such a good bet for procreation and the preservation of a diversified human race were it, incestuously, to come to it (nor will his Catalan be up to much). From the transient place of the ruined camp site where Kai is born to the long empty vista of eerily (or inexplicably) thriving fruit trees where Alba ends her voice-over monologue and the filming she has been doing on her (equally inexplicably) still functioning, but very much out of place, mobile phone camera. The 
question is does Alba belong? Does Kai? Both become nobodies nowhere, figures in discordant landscapes where there are fractures in conventional family structures and question marks over posterity and survival. In this way, as Jones suggests of the 'postnational category of films', 'longstanding narratives evident in Preserved and to some extent parodied in Reversal become mislaid or even abandoned' ${ }^{48}$

However, from the point of view of performance here, what is more often mislaid is credibility. As at least one well attuned blogger has noted, there is a notable mismatch between the film's polished technical finish and the ability of the younger actors. Rachel Hurd-Wood (as Alba) is not able to make her arrestingly gentle physical presence energise the dialogue she has with Andrés Batista (as the young Dídac) or Ibrahim Mané (the older Dídac). ${ }^{49}$ Mané only really has presence when on his own —as in a highly manipulated and manipulating scene where he stands on the pitch among the ruins of the Camp Nou stadium cradling the football that connects him back to an adolescence full of innocent dreams as well as to the moment of catastrophe, when he dives into the water in pursuit of the ball just as the air above is racked by fire. The ball and the European Cup football trophy that the couple find in their scavenging and take with them to the beach campsite signal traditional patrilineal futurity, another longstanding narrative that becomes mislaid, indeed, in this film.

A characteristic of postnational film is that identities do not stem from binaries, as mentioned in our introduction. Gender is less significant as a marker or as a point of contestation than in Preserved or Reversed; stereotypical modes of self-presentation and social practice are less are less likely to be enacted or scripted as crucial to the film's plot. As a consequence, the forms of patriarchy and feminist resistance to these can be expected to be

\footnotetext{
48 Jones, 'Changing Narratives of Identity', 88.

49 Xavier Vidal, 'Apocalipsis “made in Catalonia”: Segon origen (Segundo origen) de Carles Porta', <http:// cachecine.blogspot.co.uk/2015/12/critica-segon-origen-segundo-origen-de.html> (accessed 4 June 2018).
} 
both less evident. In both Segon origen and Los últimos dias maternity and emergent parenthood are core to the plot and they exert, not unexpectedly, a substantial pull towards the Preserved. In terms of genre, the tale of the father desperate to be reunited against catastrophic odds with the mother of his about-to-be-newborn child is effectively conventional and constitutes a highly binaristic, heroic narrative. On the other hand, Marc and Júlia do their parenting in a context largely free of stereotypical models (beyond what they both might have internalised from their pre-apocalyptic past) and it is the act of giving birth that becomes the ultimate quest fulfilment and challenge to secure a future. Júlia having been largely an inactive presence (lost, waiting) throughout the film's narrative is at last a powerful figure in a potentially post-patriarchal new world. She and Alba, in Segon origen, hint at a feminist Project identity (in Castell's terms). Alba's pregnancy and her breastfeeding of Kai supply warm, affective imagery to the film; her determination to rescue, care for, and reconstruct a future with her child are powerful narrative drivers in the Reversed mode. Her audibly late adoption of the linguistic heritage of Catalan is in tune with her sudden positioning at the start of a myth of regeneration nourished, as has been seen, by onscreen references to the earth, fertility, and mediterraneïtat. In a sense, and perhaps despite itself and despite its own origins, the film might also posit a new Catalan but postnational feminist world in which (depending on how her son develops away from the Biblical antecedent that is implied) Alba's word is foundational but productively uncertain. 50

\footnotetext{
50 We are grateful for the important suggestion by an anonymous reader of an earlier version of this article that a productive comparison might here be made with the treatment of the gendered dynamic between the non-verbal and the patriarchal-logocentric in Bigas Luna's Son de mar (2001).
} 


\section{Estiu 1993: postnational, Preserved, and Project}

Estiu 1993/Summer 1993 (Carla Simón, 2017) is set largely in the Parc Natural de la Zona Volcànica de la Garrotxa and filmed partly in and around the director's home village of Les Planes d'Hostoles. The website of CatalanFilms\&TV has the following very brief synopsis: 'Frida, a six-year-old girl, faces the first summer of her life with her new adoptive family after her mother's death'. ${ }^{51}$ Her mother, Neus, has died of AIDS-related illness and Frida (Laia Artigas) leaves Barcelona and the care of her grandparents (mirroring Simón’s own transition at the same age from, in her case, Badalona) to go and live with her uncle Esteve and his long-term partner Marga on the outskirts of a small rural community. As variously noted, the quality of the acting, notably by the young Laia Artigas, the vivid palate and use of period detail, the delicate treatment of grief, loss and change have all contributed to a very high dual-national and international profile for the film, especially on the festival circuit. ${ }^{52}$ With nominations in fourteen categories and awards in five in the 2018 Gaudí awards of the Catalan Film Academy, including best script and direction, it has been cited as a key film for

51 CatalanFilms\&TV, 'Estiu 1993', <http://catalanfilms.cat/ca/productions/summer-1993> (accessed 15 April 2018).

52 Andrea G. Bermejo, 'Verano 1993', <http://cinemania.elmundo.es/peliculas/verano-1993/critica/> (accessed 15 April 2018); Jordi Costa, 'Les llàgrimes de la Frida', <https://cat.elpais.com/cat/2017/06/29/cultura/ 1498688893_832834.html> (accessed 15 April 2018); Eulàlia Iglesias, 'Estiu 1993: la nena que no plorava', < https://play.ara.cat/cinema/Estiu_0_1823817628.html> (accessed 15 April 2018); Dominique Martinez, 'Été 93 : La prose tranquille de l'ardeur', Positif, 677/678 (2017), 120-21; Marta Medina, 'Estiu 1993: un milagro catalán en la Berlinale', <https://www.elconfidencial.com/cultura/2017-02-13/berlinale-estiu-1993-catalan-historiareal_1330232/> (accessed 15 April 2018). On the festival successes, see CatalanFilms\&TV, CatalanFilms\&TV, 'Estiu 1993'. 
a new moment in Catalan Cinema by Isona Passola, the president of the Academy. ${ }^{53}$ Further signs of its cultural distinctiveness are: its development of the idea of a recognisably Catalan heartland as a green, sacred place of affinity and healing, its use as a key plot motif of a parade of Gegants i Capgrossos — an archetypically localist popular event with strong associations since the 1980 s with the affirmation and celebration of Catalan exceptionalismand its subtle reconstruction of the specific popular cultural moment of the early 1990s, as observed by Catalan critic Eulàlia Iglesias. ${ }^{54}$ In particular, it documents a generation of early thirty-somethings in search at the time of a quasi-utopian, liberated alternative to urban, Catalan (and Catholic) bourgeois life, as Dominique Martinez has noted. ${ }^{55}$ Neus's lifespan, indeed, covers from the late 1950 s to 1993 - a transition for Catalunya from dependency under the repressive centralist policies of Francoism in Spain, through the approbation of a Statute of Autonomy and associated measures in 1979, on into an evolving and renascent cultural identity and nationality and the consolidation of the new-era Generalitat de Catalunya.

The child's perspective, through Frida, also connects the film-for certain audiences - to wider Spanish contexts of imagistic and dramatic explorations of the interconnectedness of family, fantasy, history, identity, innocence and violence. ${ }^{56}$ Simón herself has avowed in interviews her interest in Víctor Erice's El espíritu de la colmena (1973) as well as Carlos

\footnotetext{
53 Esteve Plantada, 'Estiu 1993 i Júlia Ist, les darreres benediccions del nou cinema català', <https:// www.naciodigital.cat/noticia/134732/estiu/1993/Júlia/ist/darreres/benediccions/nou/cinema/catala> (accessed 15 April 2018).

54 Eulàlia Iglesias, 'Estiu 1993'.

55 Martinez, 'Été 93'.

${ }^{56}$ As studied comprehensively by Sarah Wright, The Child in Spanish Cinema (Manchester: Manchester University Press, 2013).
} 
Saura's Cría cuervos (1975) alongside directors Alice Rohrwacher and Jacques Doillon. ${ }^{57}$ These connections were picked up on by critics early on. 58 The salience of family both as a dependable framework for Frida's coming of age and as a site of displacement and disturbance is established in the second sequence of the film, as Frida's aunts-Neus's sisters Àngela (Berta Pipó) and Lola (Montse Sanza), with Marga and (less actively) Esteve—-sort and pack various items into boxes, with the young, orphaned Frida framed so as to be a distant observer from doorways, the corridor, or listening in from another room. The camera is the eye and the sound equipment the ear of Frida; when she does quietly walk into the bedroom, recently vacated by the busy women, her glance alights on a multi-pack of Hidalgo brand cigarettes, two blouses (from Morocco, as Marga and Àngela are heard saying — one of several items in the room from that iconically alternative destination), the stripped bed and suitcases; the camera then separates itself from her POV to show an empty chair, which Frida then occupies, listening to Esteve struggle gently through the melancholy rumba classic 'Sabor de barrio', before being asked to play 'Neus's song'. The song is then not heard, as the scene cuts to Frida being taken through the Lord's Prayer, being urged to recite it each night, and given Neus's First Communion certificate (dated 1963) by her grandmother (Isabel

\footnotetext{
${ }^{57}$ Abycine, 'Entrevista a la directora de Verano 1993: Carla Simón, finalista de Abycine-Lanza 2016’, <http:// www.abycine.com/noticias/entrevista-Carla-Simon/> (accessed 15 April 2018); María Aller, 'Carla Simón: la directora que ha emocionado en Málaga', <http://www.fotogramas.es/Festival-de-Malaga/2017/entrevista-carlasimon-verano-1993-malaga> (accessed 15 April 2018); Magdalena Tsanis, ‘Carla Simón, la revelación del cine español de 2017 con Verano 1993', <https://www.elconfidencial.com/ultima-hora-en-vivo/2017-06-26/carlasimon-la-revelacion-del-cine-espanol-de-2017-con-verano-1993_1253029/> (accessed 15 April 2018). 58 Bermejo, 'Verano 1993'; Martinez, 'Été 93'; Carlos Reviriego, 'Verano 1993 o la infancia quebrada'. El Cultural Print edition, 30 June 2017; available at: $<$ http://elcultural.com/revista/cine/Verano-1993-o-la-infanciaquebrada/39837> (accessed 15 April 2018).
} 
Rocatti) in a clear display of traditional Catholic values such as would have been hegemonic while Neus was growing up but which all the evidence around already suggests she had distanced herself from. Next, while Lola is packing away Frida's comforter blanket with its pink-rabbit motif - a cosy, jokey little anticipation of the rural world around the corner, perhaps--Frida asks her why she is not coming with them, only to get a vague promise of a future visit; here, then, is a vital emotional connection for Frida that gets severed. In a further lack of connection to the new life awaiting her, Esteve and Marga have come down into the city without their daughter Anna (Paula Robles), the younger cousin who might have helped make the transition smoother. Anna, indeed, is the only main character not on screen in this transitional sequence, signalling the adults' lack of full cognisance of what they are taking on and a kind of family dysfunction more characteristic of the Reversed mode.

As has been seen, in the introduction, Reversed refers to the reversal of dualisms on which the category of Preserved is built. As a consequence of this reversal, the longstanding, simplistic narratives of identity that defined Preserved are critiqued in the kind of deconstructive process that according to Jacques Derrida and Jameson expose the working of fundamental elements in narratives of identity. 59 In this film this reversal of dualisms can be seen in relation to family structure and roles within the family. Whereas Preserved is built around patriarchal structures and roles, Reversed is matriarchal, and often associated with the collapse of longstanding versions of masculinity. For instance in this film the grandfather (Fermí Reixach) is a mute, powerless figure; additionally, the peripherality of Esteve in the apartment scene clearly signals his rejection of traditional Catholic upbringing in favour of

\footnotetext{
59 Jacques Derrida, 'Différance', in Jacques Derrida Margins of Philosophy, trans. Alann Bass. (Brighton: The Harvester Press, 1984), 1-28; Fredric Jameson, 'Postmodernism and Consumer Society', in The Cultural Turn: Selected Writings on the Postmodern 1983-1998 (London: Verso, 1998), 1-20.
} 
an alternative lifestyle, highlighting the theme of generational schism in the film. The continuity associated with Preserved is disrupted.

The exit from the town, down the street—festive with fireworks — and shut away in the car (sounds of an anyway terse farewell dialogue and street sounds alike muffled) happens in silence for Frida, clinging to her baby doll. Family proper has failed in these moments to give her anything more to hold to. The turmoil and confusion of the adults' activities — variously goal-oriented and effectively indifferent to what Frida might be going through — is behind her. In the car, enclosure anticipates the dramatic development, in Frida, of the motif of contained grief. It also signals her apprehension about leaving the urban for the rural, whose initial strangeness is soon to be revealed as discordant - more a landscape of lost or confused identity, more a postnational place, than a place of nurture, a cradle of the Preserved. Later in the film, following a visit by the grandparents and Lola, Frida refuses to leave the car when they are due to be taken back, seeing the urban other family momentarily at least as the homeland for her. In parallel, the true sense of belonging that is developing is that to the countryside and the new family which become home in a way that accords with the Preserved - the powerfully seductive representation of the landscape and of her feelings underline this.

\{FIGURE 5 of 6 near HERE: shrine. Caption: Frida (Laia Artigas) making a woodland offering to her mother's memory in Estiu 1993. Courtesy of Inicia Films\}

Despite Frida's waxing and waning sense of dislocation as the film moves on, the basic narrative trope is, then, that of the abandonment of the urban and enclosed for the rural and more open. The lusciously filmed natural, forested spaces, the small shops and school 
and church and square of local community, and the earthy homeliness of Esteve and Marga's late-hippy-cum-early-eco-aware arrangements, all construct a safe, and at times a sacred, space for new beginnings and for Frida to come to terms with her grief and loss. A small woodland shrine to the virgin is co-opted by Frida as a place to make offerings to and invoke the spirit of her mother-specifically, including one of Neus's blouses, and, later, a pack of the cigarettes previously glimpsed as a token of Neus's rebellious energies. This is all highly characteristic of the Preserved mode - the rural landscape resolves itself at the end of the film as a landscape that nurtures and heals; and the resolution of Frida's relations with the new family seems to be formed of a combination of people and landscape in a relationship of coconstruction. However, just as Frida's grandmother signals the reactionary dominant attitudes of the generation of the time of Neus's birth (in the early to mid-1950s) the rural community, though nurturing the open, the holistic and the alternative, is not without its sharp instances of repression. In particular, mapped discordantly onto the history of progressive Catalunya within a highly liberalised Spain by the early 1990s is a micro-history of ill-informed and prejudice-ridden social attitudes to HIV and AIDS.

\section{\{FIGURE 6 of 6 near HERE}

\section{Caption: Frida (Laia Artigas) getting a blood test in Estiu 1993. Courtesy of Inicia}

\section{Films\}}

The importance of HIV and AIDS as a plot motif is signalled early on in the film when we see Frida watching the needle going into her arm as she has a blood test at the local hospital, after a fractious drive through the rural landscape. In a visit to the local butcher's shop, neighbours recognise Frida and resurrect gossip concerning Neus's final illness, 
referencing HIV/AIDs tacitly in the blatant euphemism 'una altra cosa' (something elseother than pneumonia, that is). When Frida trips and cuts her knee at an early visit to the playground - a space already structured round the typical minor cruelties of children confronting incomers - her new friend Irene (Etna Campillo) is hustled away from even looking at the small amount of blood by her panicking mother Cesca (Paula Branco), antiseptic wet-wipes but no explanation for her behaviour to hand. The (implied) blood of the butcher's counter — where a pinkly skinned rabbit is being dismembered for a customer — and the blood of the cut knee are supplemented elsewhere in the film by further images of blood. In one case, when Frida has followed Marga into the toilet, concerned that she is ill (she is having her period), the camera from over Frida's shoulder fixes briefly on a menstruation pad being dropped into the bin by the toilet; the association with illness cannot be shaken from Frida's mind. In another, a sheep is slaughtered in the yard outside, the morning after Frida has made a night-time visit to the virgin in the woods (calling out 'Mama?', and searching around); the camera (from Frida's POV) lingers on the blood running into a bucket from the animal's neck. Here the association is again with death and perhaps sacrifice; as thunder quietly rumbles in the distance, the scene is given a subtle tinge of the ritualistic and the ominous. Close to the end of the summer and the end of the film (and the Frida's first shedding of tears), as preparations are made round the table for the start of school, Frida asks Marga how Neus had died, and had there been blood? The film, then, activates the child's fascination with blood, and with the dead (as does El espiritu de la colmena); but it also uses blood to connect to a sector of the adult world's anxieties about contagion, uncleanliness and quarantine. Those in the rural community who are affected by these anxieties are playing out the narratives of the Preserved mode of representation where the other and the modern is marginalised and excluded. Indeed, the film contains a number of features associated with the 
category Preserved. To recapitulate: the preparation and parading of the Gegants i Capgrossos celebrates a distinctive feature of Catalan culture; the rural setting is presented as a nurturing, restorative heartland or cradle of Catalan culture; represented as locked into a relationship of co-construction with a segment of an identifiably Catalan people, the rural situates the individual and the collective. The rural also seems to restore or cure Frida, offering her a sense of self beyond loss; the local community is also a survivor, implicitly, of the oppression of the Franco years and with its distinctive identity largely intact. Finally Marga, though progressive, is depicted within the traditional domain for women, that of domesticity and responsibility for childcare. Montserrat Guibernaud and Michael Keating are among those scholars who highlight the complex interactions in the building of a sense of nationhood of collective identity, social solidarity, and community of culture. ${ }^{60}$ Here these cohere around a series of dualisms - topographical and temporal — that the film uses delicately to build its narrative, dramatic and psychological structures.

However, equally important to the structuring and impact of the film are its postnational features (that also, as will be recalled, enfold the Preserved and Reversed): there is a rupture with family history as much as a remaking of family, a discordant landscape as much as a rural idyll, and a sense of uncertainty concerning the future as much as a reaffirmation of the certainties and solidarities of the local. 


\section{Conclusions}

This article has described links between the Castells's more broad-scale, sociologically oriented conceptions of significantly different typologies of identities and power relations and Jones's film-focused ones. It has sought to illustrate how Jones's classificatory system for films is applicable to three recent Catalan films, and how this classificatory system assists in the analysis of narratives of identities in these films, as well as relations between characters, and between characters and landscape.

In a variety of different ways, the three film examples discussed can be seen to depict Catalonian identities as, variously, traditional and stable, under threat, and increasingly absent, in harmony with Jones's three distinct categories of film. Analysis in this article also demonstrates how individual films can incorporate elements of more than one of Jones's categories. Whilst the films discussed incorporate many elements associated with the category postnational, with all the uncertainties associated with it, they can also be seen in different degrees and aspects to retreat towards a comfort blanket of traditional, well worn narratives of identities and social relations, towards the certainties promised by generic expectations, and towards time-honoured (if not always successful) filmmaking tactics. Emerging as they have done at a time of acutely pressing transition in Catalunya they bring some telling metaphors, perhaps, onto international screens large and small. *

\{Table 1 of 1 here\}

*Disclosure Statement: No potential conflicts of interest were reported by the authors. 